\title{
Recorregut de recerca geològica i mineralògica per les comarques del Baix Ebre i de la Ribera d'Ebre: des del Perelló a l'antic circuït de Calafat i a Tivissa
}

Josep Maria Mata-Perelló

Joaquim Sanz Balagué

\section{XARAGALL \\ REVISTA DE CIÈNCIES DE LA CATALUNYA CENTRAL}

\section{n. 3}

MARÇ 2015 


\title{
RECORREGUT DE RECERCA GEOLÒGICA I MINERALÒGICA PER LES COMARQUES DEL BAIX EBRE I DE LA RIBERA D'EBRE: DES DEL PERELLÓ A L'ANTIC CIRCUÏT DE CALAFAT I A TIVISSA
}

\author{
Josep Maria Mata-Perelló \\ Museu de geologia Valentí Masachs, Escola Politècnica Superior d'Enginyeria de Manresa \\ (EPSEM), Universitat Politècnica de Catalunya · BarcelonaTech (UPC), 08272 Manresa, Spain
}

\section{Joaquim Sanz Balagué}

Departament d'Enginyeria Minera i Recursos Naturals (EMRN), Escola Politècnica Superior d'Enginyeria de Manresa (EPSEM), Universitat Politècnica de Catalunya . BarcelonaTech (UPC), 08272 Manresa, Spain

Paraules clau: Sistema Mediterrani, Patrimoni miner

\begin{abstract}
Resum
Itinerari realitzat el 12 d'abril de 2014. En aquesta ocasió, el recorregut de l'itinerari discorrerà, en la seva totalitat pel Sistema Mediterrani (i més concretament per la seva sots-unitat més interna, la Serralada Prelitoral Catalana). Així, transitarà pràcticament per aquesta sots-unitat geològica, entre les localitats del Perelló (Baix Ebre) i Tivissa (de la Ribera d’Ebre).

D'aquesta forma, al llarg de tot el recorregut, anirem trobant afloraments eminentment carbonatats (sovint també calcolutitic), del Juràssic i del Cretàcic, segons els indrets per on es desenvolupi el recorregut de l'itinerari

Per altra banda, el recorregut s'iniciarà a la localitat del Perelló (Baix Ebre) per a finalitzar prop de Tivissa (Ribera d'Ebre). Així, d'aquesta forma, transcorrerà per dues de les comarques de I'Ebre.
\end{abstract}




\section{Objectius fonamentals}

En realitzar el següent itinerari, s’intentaran assolir els següents objectius fonamentalment:

1. Estudi i observació dels materials mesozoics (representat per tots els seus trams, segons els indrets), els quals formen part de la Serralada Prelitoral Catalana. Aquests materials els trobarem a la major part del recorregut de l'itinerari, entre el Perelló (per on ho predominen els materials del Juràssic i els del Cretàcic) i Tivissa (per on predominen els materials del Triàsic).

2. Observació, si s'escau, dels materials miocènics (coberts en la seva major part pels terrenys quaternaris del Pleistocè i de l'Holocè), els quals reblen la Depressió Prelitoral Catalana. Els trobarem exclusivament pels voltants del poble del Perelló, en alguns sectors del tram inicial del recorregut de l'itinerari.

3. Estudi de les relacions existents entre les dues unitats geològiques acabades d'esmentar, entre la Depressió Prelitoral Catalana i la Serralada Prelitoral Catalana; i també entre les dues branques en les quals es subdivideix aquesta darrera; així com a la Depressió de Mora, situada entre elles. Al respecte de les dues branques de la Serralada Prelitoral Catalana, cal dir que una petita part del recorregut, entre les poblacions de Rasquera i el Perelló, el recorregut incidirà molt breument per la Branca Interna de la Serralada Prelitoral Catalana, i més concretament pel denominat Bloc de Cardó. En canvi, tota la resta del recorregut transitarà per la serralada pròpiament dita.

4. Estudi, si s'escau, d'algunes mineralitzacions situades entre els materials mesozoics de la Serralada Prelitoral Catalana. Entre aquestes, farem esment de:

4A) les mineralitzacions ferruginoses associades a "hard-ground", que es veuran al Perelló (Baix Ebre), entre les calcàries juràssiques, i

4B) les mineralitzacions ferruginoses de rebliment de cavitats d'origen càrstic. Aquestes es troben localitzades a Tivissa (Ribera d’Ebre), entre les calcàries del Juràssic.

5. Observació de les explotacions, relacionades amb les mineralitzacions, que anirem veien al llarg del recorregut. I, en veure-les, s'intentarà observar el grau de restauració que s'ha produït en elles.

6. Observació i valorització de diferents aspectes relacionats amb el Patrimoni Geològic i Miner.

7. Observació de l'impacte produït per les explotacions anteriors (i també per les vies de comunicació o altres actuacions antròpiques) sobre el Medi Natural i sobre el Medi Ambient. 


\section{Antecedents}

Tret de dos antecedents nostres (Mata Perelló, 1998c i 1998d), no tenim coneixement de I'existència de cap altre antecedent bibliogràfic de caire total, en relació amb el recorregut d'aquest itinerari. Tot i així, existeixen diversos antecedents parcials, corresponents a trams del mateix. Entre aquests, farem esment d'alguns antecedents nostres, pel que fa als itineraris geològics i mineralògics, que discorren per aquestes terres, relatius als darrers anys Mata Perelló (1996, 1997, 1998a, 1998b i 2000).

Pel que fa a l'estudi de les mineralitzacions situades al llarg del recorregut, farem esment d'un altre treball nostre, Mata Perelló (1991), relatiu al conjunt de les mineralitzacions situades arreu de Catalunya. També farem esment de la recent publicació de l'IGME (1993), relativa al full metalogenètic de Tarragona.

I, pel que fa a l'estructura geològica dels indrets pels quals discorrerà el recorregut de l'itinerari, farem esment de dos treballs generals, relatius al conjunt dels Països Catalans: Guimerà et altri (1992), i Riba et altri (1976). En aquest aspecte, també farem esment de les publicacions de I'ITGME (1978a, 1978b, 1978c, 1978d i 1986), relatius a les contrades per les quals discorrerà el recorregut d'aquest itinerari.

Tots aquests treballs esmentats, figuraran per ordre alfabètic a l'apartat dedicat a les REFERĖNCIES BIBLIOGRÀFIQUES, al qual ens remetem.

\section{Recorregut de l'itinerari}

El recorregut d'aquest itinerari comença per les immediacions de la població del Perelló. però fent una aturada abans d'arribar-hi. Tot seguit, es continuarà per I'antic tram de la carretera N340, cap a les immediacions de Calafat, per tal d'arribar abans a Mas Plater, per tal de fer una aturada a una antiga mina de ferro, situada a l'extrem meridional del terme de Tivissa, prop de Mas Fabià. En aquest tram, s' haurà passat del terme del Perelló (al Baix Ebre) a l'esmentat de Tivissa (de la Ribera d’Ebre).

Després, a partir d'aquest indret, el recorregut es dirigirà cap el poble de Tivissa, per on es faran diverses aturades. Finalment, en arribar a aquest darrer poble, es clourà el recorregut d'aquest itinerari. 


\section{Advertiments previs}

Com en altres recorreguts de RECERCA GEOLÒGICA I MINERALÒGICA... si es disposa del temps suficient, poden efectuar-se passant per totes les parades i filloles. En cas contrari, recomanem reestructurar el recorregut, prescindint de les anomenades PARADES CONDICIONALS, i d'altres si s'escau.

També recomanem de cercar la informació més adient, sobre els trams a recórrer mitjançant camins de terra, o de pista. Precisament, en aquest itinerari, hi ha alguns trajectes d'aproximació cap a les mines de Mas Plater (o de Mas Fabià), que haurem de fer per camins de terra en irregular estat de conservació.

Per altra banda, recomanem tenir una cura extrema de la NATURA, evitant qualsevol forma d'agressió sobre ella, o de fer-n'hi un mal ús del que en ofereix la nostra mare Terra.

\section{Descripció de l'itinerari}

Com en altres itineraris, a continuació veurem una sèrie de "parades o estacions". En cada una d'elles es farà un breu comentari. Per d'altra banda, darrera del nom de l'indret (o de la parada), situarem entre parèntesi el número del Mapa Topogràfic, a escala 1:50.000, on es troba l'indret de l'aturada. En aquesta ocasió, utilitzarem solament quatre fulls de l'esmentat mapa topogràfic, editat per I'"Instituto Geográfico y Catastral": concretament dels següents: 471 (dit de Mora d’Ebre), $\mathbf{4 7 2}$ (dit de Reus), 497 (dit del Perelló) i finalment del $\mathbf{4 9 8}$ (dit d’Hospitalet de I'Infant).

Així doncs, la relació ordenada, de les parades que composen el recorregut d’aquest itinerari. és la següent:

\subsection{Parada 1. MINA DE FERRO DE LES COMES, (terme municipal del Perelló, comarca del Baix Ebre). (Full 497).}

En aquest indret s'iniciarà aquest itinerari, concretament per les immediacions de la carretera TV-3022, la qual procedeix de la població de Rasquera; concretament, a poc més de $2 \mathrm{Km}$ del nucli del Perelló. Així, en aquest indret farem la primera aturada, del recorregut d'aquest itinerari.

Aquest indret es troba situat a la Serralada Prelitoral Catalana, entre afloraments dels materials mesozoics carbonatat, del Cretàcic (que predominen pels voltants del Perelló) i del Juràssic. Aquests darrers són precisament els que apareixen per les proximitats de l'indret de la present aturada.

Concretament, a l'indret de la parada, es troba una mineralització ferruginosa associada a "hard-grond". Aquest, s'ha desenvolupat sobre unes calcàries mesozoiques del Juràssic, discordants amb nivells Cretàcics (del Barremià), que eles cobreixen.

Entre els minerals de ferro presents, cal fer esment de la presencia de la roca LIMONITA (terrosa, amb GOETHITA, LEPIDOCROCITA i SIDEROGEL), així com dels minerals de ferro: HEMATITES (terròs) i SIDERITA (testimonial). Altres minerals presents, són els següents: PIROLUSITA (dendrítica), CALCITA i DOLOMITA. 
Finalment, cal dir que aquesta mineralització va ésser explotada, sense gaire èxit, durant el segle XIX, i principis del segle XX. Així, en aquest indret va haver-hi una antiga explotació dels minerals de ferro. Tot i això es difícil de reconèixer-la, encara que l'escombrera es fa força palesa. (fotografia 1).

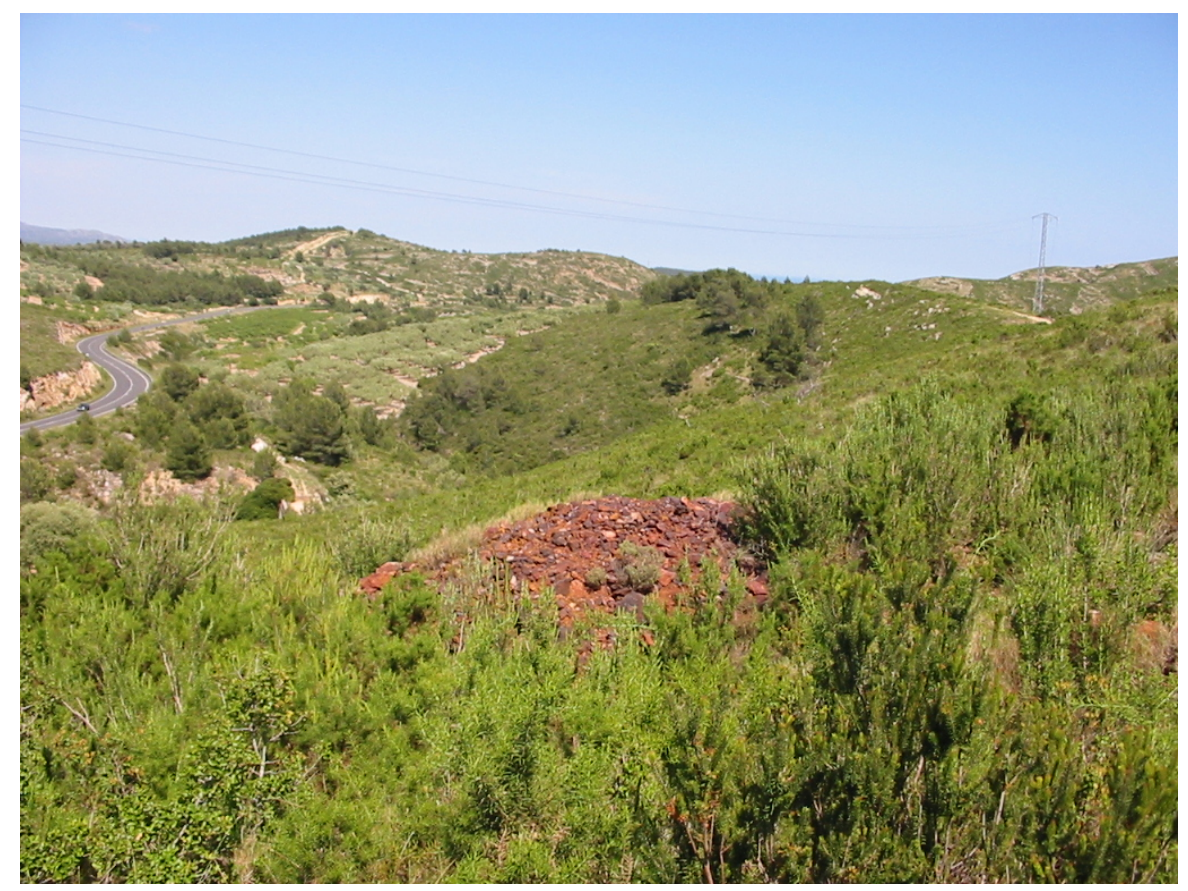

Fotografia 1. Escombrera de les antigues Mines de Ferro de les Comes. El Perelló

\subsection{Parada 2. MINA DE FERRO DEL MAS PLATÉR O DEL MAS DE FABIÀ, (terme municipal de Tivissa, comarca de la Ribera d’Ebre). (Full 497).}

Des de la parada anterior, cal continuar, per la carretera local TV-3022, cap al Perelló. Des d'aquí caldrà sortir per la carretera nacional $\mathrm{N}-340$, amb la intenció d'arribar al trencall d'on eix la carretera cap a I'Ametlla de Mar. Just d'aquest trencall, caldrà agafar la carretera local TV - 3025, que en part coincideix amb l'antiga N - 340. En arribar al Mas Plater, ens caldrà agafar una pista asfaltada que es va dirigint cap al Barranc d'Escaldabecs. Més endavant, s'arribarà a una pedrera de calcàries i poc després es trobarà el trencall del Mas de Fabià. Després, en deixar el camí asfaltat, caldrà seguir per un camí que va remuntant. Prop, s'arribarà a les antigues Mines de Ferro de Mas Plater. (o millor de Mas Fabià). Aquí farem una nova aturada; així, des de la parada anterior, ens haurà calgut fer un recorregut proper als 13 $\mathrm{Km}$, a través dels quals hem tornat a penetrar a la comarca de la Ribera d’Ebre, deixant enrere la del Baix Ebre.

En aquest recorregut, hem anat trobant afloraments dels materials mesozoics, fonamentalment del Cretàcic, i en menys grau del Juràssic, tots ells de la Serralada Prelitoral Catalana. Molt sovint aquests materials es troben recoberts per terrenys detrítics del Pleistocè i de l'Holocè. Cal dir, que podíem haver fet una aturada intermitja, poc abans de trobar el trencall de Mas Fabià, en veure una antiga pedrera de roques carbonatades juràssiques. 
En arribar a l'indret de la parada, es troba una antiga mina de ferro, pràcticament esfondrada, la qual es relaciona amb una mineralització localitzada entre les calcàries juràssiques, la qual consisteix en un rebliment de cavitats d'origen kàrstic. Entre els minerals presents es troben la GOETHITA (terrosa i limonítica) i I'HEMATITES (també d'aspecte terrós). També es troba present la CALCITA. (fotografíes 2, 3 i esquema 1).

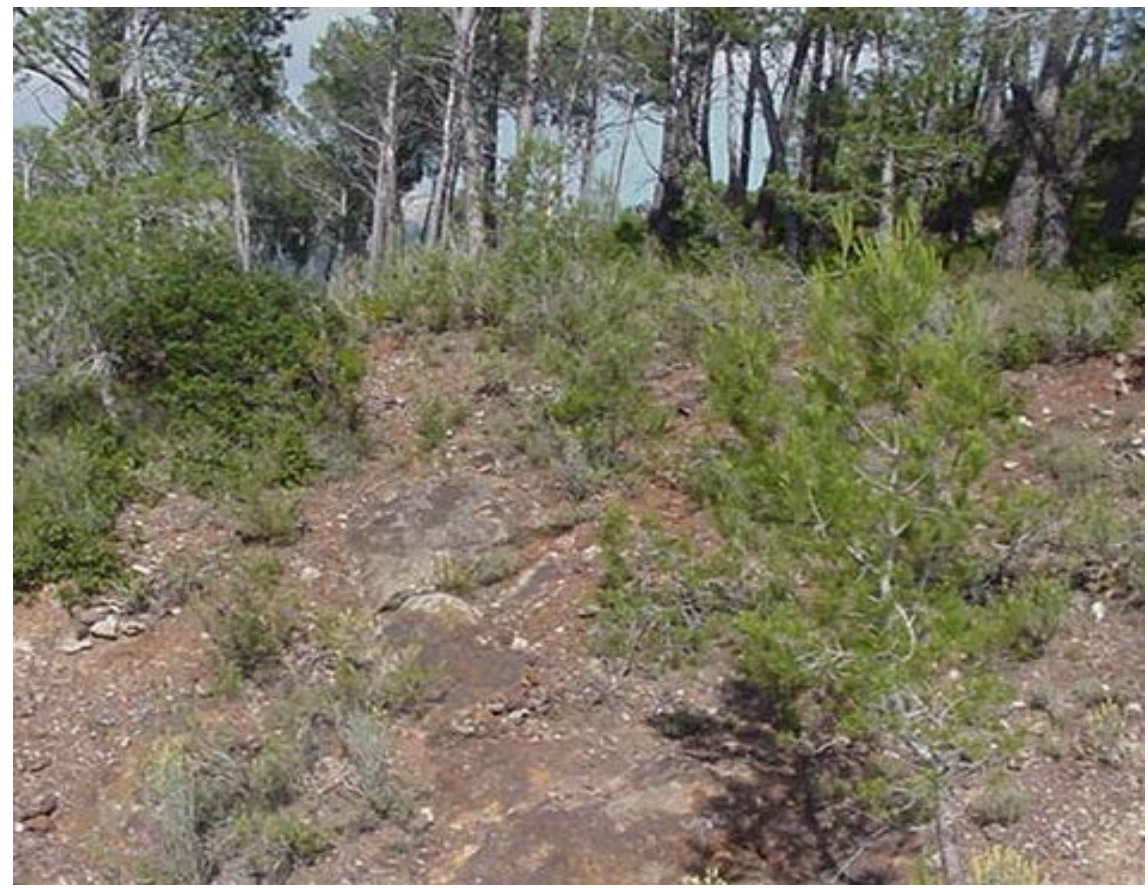

Fotografia 2. Aflorament dels minerals de ferro. Mines de Ferro de Mas Fabià. Tivissa

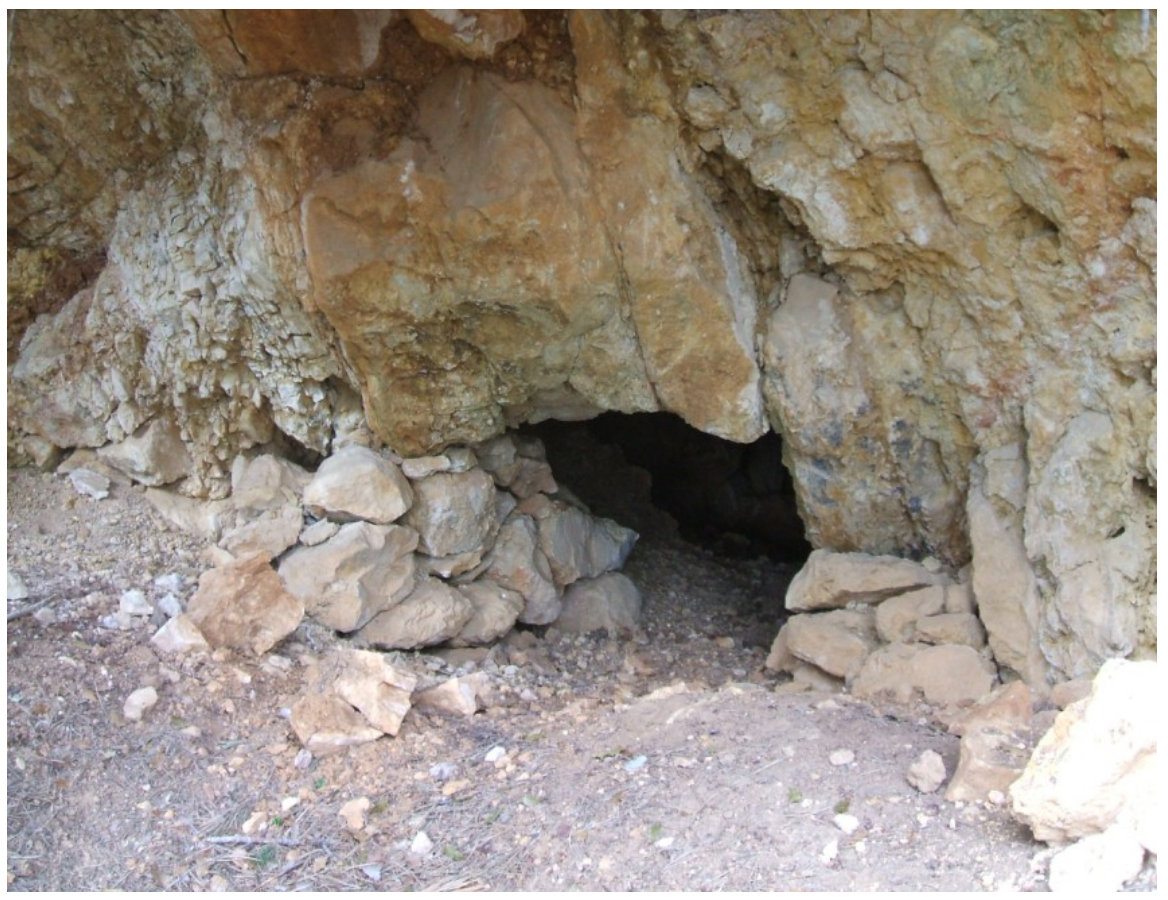

Fotografia 3. Una de les bocamines. Fotografia de Joaquim Roset 


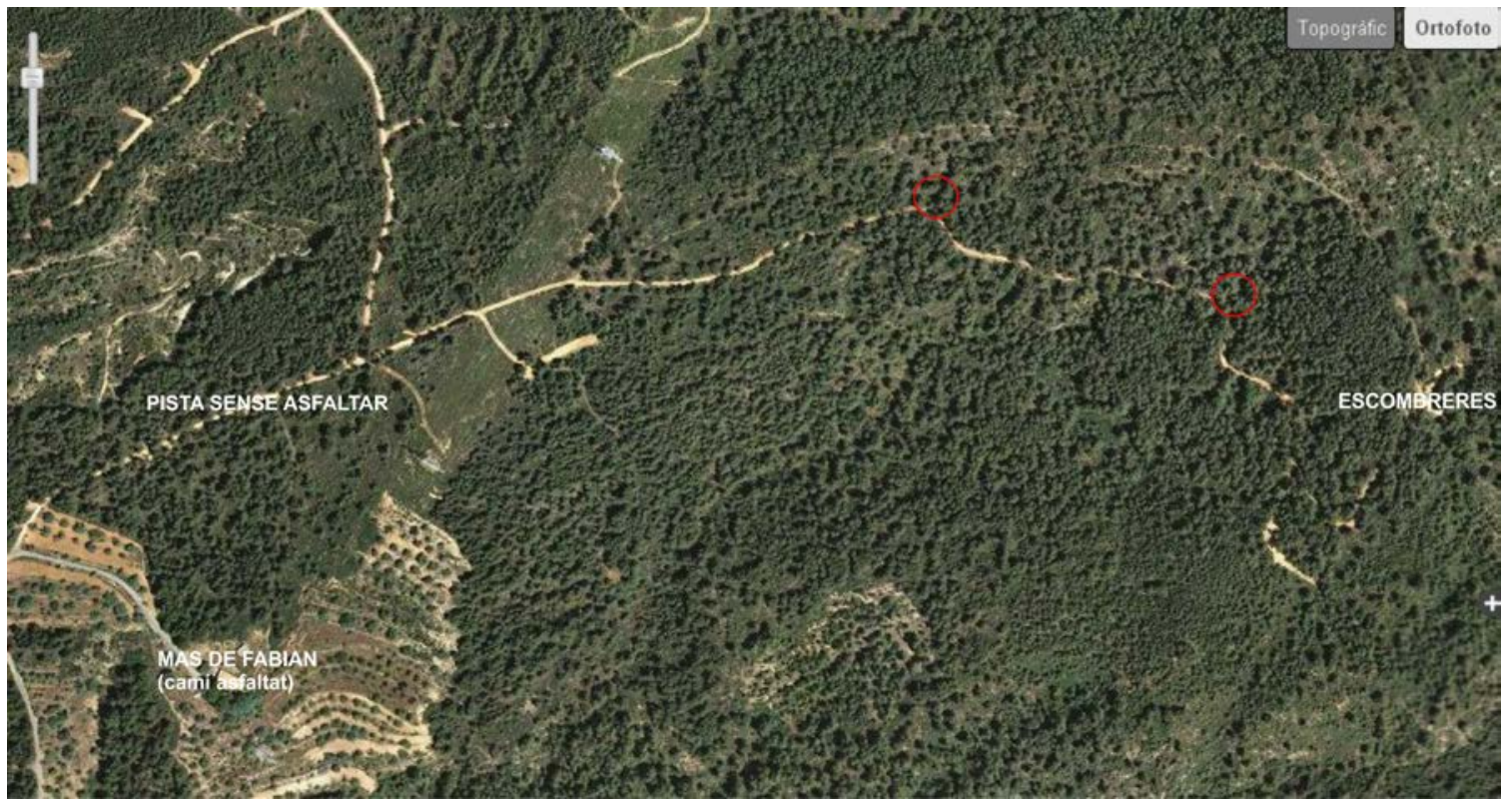

Esquema 1. Als cercles rojos es poden veure les bocamines (PARADA 2). Per d'altra banda, l'escombrera es prop del Coll de Ferro (PARADA 3)

\subsection{Parada 3 - CONDICIONAL. EL COLL DEL FERRO, (terme municipal de Tivissa, comarca de la Ribera d’Ebre). (Full 497).}

Des de la parada anterior, cal continuar a peu des de la mina, ascendint lleugerament fins arribar a l'anomenat Coll de Ferro, per on farem la present aturada. Així, des de la parada anterior, ens haurà calgut fer un recorregut proper als $0^{\prime} 2 \mathrm{Km}$.

En aquest recorregut, hem continuat anat trobant afloraments dels materials carbonatats mesozoics, fonamentalment del Cretàcic Inferior (concretament del Barremià); i també del Juràssic. Aquests materials pertanyen a la Serralada Prelitoral Catalana, i formen part de la Serra de Batalla.

En aquest indret hi ha agut una petita explotació dels minerals de ferro (que hem vist a I'aturada anterior). Aquesta explotació es va realitzar a cel obert. També, prop d'on ara som, es pot veure una antiga escombrera, amb abundants restes dels minerals i roques del ferro.

Un esquema indicatiu, sobre l'ortofoto de la zona, es pot veure al PLA DE SITUACIÓ, elaborat per Joaquim Roset. 


\subsection{Parada 4. IMMEDIACIONS DE MAS SAUVELLES, (terme municipal de Tivissa, comarca de la Ribera d'Ebre). (Full 471).}

Des de la parada anterior, cal retrocedir fins més enllà de Mas Fabià, per tal de continuar pel camí asfaltat que va conduint cap el NE, cap a Gavadà. Més endavant, després de sobrepassar una forta pujada, per l'esquerra es trobarà un camí (de vegades no gaire bo) que va conduint cap al Mas d'Aumet. Així, haurem fet uns $4 \mathrm{Km}$ des de la parada anterior. Tot i així, caldrà seguir, ara cap al Coll de Maula. Poc després de sobrepassar el Mas Sauvelles, podem fer una nova aturada, a uns $5 \mathrm{Km}$ del Mas d'Aumet i a uns 9 de la parada anterior.

En aquest recorregut, hem continuat trobant afloraments dels materials mesozoics, dels que hem parlat als recorreguts anteriors. Aquests materials són eminentment carbonatats i pertanyen al Juràssic i al Cretàcic. Tot i així, prop del Mas d'Aumet, hem trobat uns afloraments dels materials Triàsics (amb calcàries del Muschelkalk i nivells d'argiles i guixos del Keuper). Aquests materials es troben en contacte per falla amb els anteriors.

Per altra banda, poc després de sobrepassar el Mas Sauvelles, veurem a l'esquerra del camí, un lliscament produït per un terratrèmol a l'any 1845 . Aquest és pot veure a mitja vessant de I'indret per on fem el recorregut.

\subsection{Parada 5. LES MELIQUES, PORTELL DE CASES, (terme municipal de Tivissa, comarca de la Ribera d'Ebre). (Full 471).}

Després de fer l'aturada anterior, cal continuar pel camí que es va apropant cap el Coll de Maula i també cap a Tivissa. Poc després de sobrepassar el Portell de Cases, a les Meliques, podem fer una nova aturada. Així, haurem recorregut uns $3 \mathrm{Km}$ més, des de l'aturada anteriorment efectuada.

En aquest recorregut, hem continuat trobant afloraments dels materials carbonatats (ocasionalment de caire calcolutitic). Aquests materials pertanyen en tot aquest tram al Juràssic, localitzant-se dintre de la Serralada Prelitoral Catalana. En aquest indret, podem veure un interessant tren de plecs, ocasionalment molt estrets en forma de chevron. (fotografia 4).

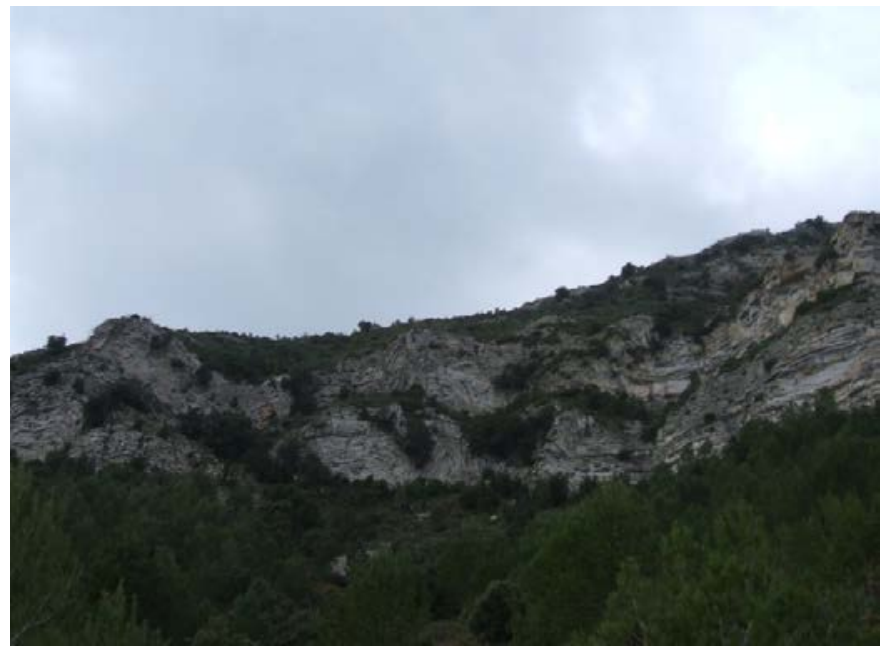

Fotografia 4. Tren de plecs (amb plecs chevron) entre els afloraments juràssics de les Meliques. Fotografia de Joaquim Roset 
Per altra banda, a escassa distancia d'aquest indret, es pot veure un descomunal despreniment, amb abundants blocs caiguts, entre els nivells carbonatats juràssics. (fotografía 5).

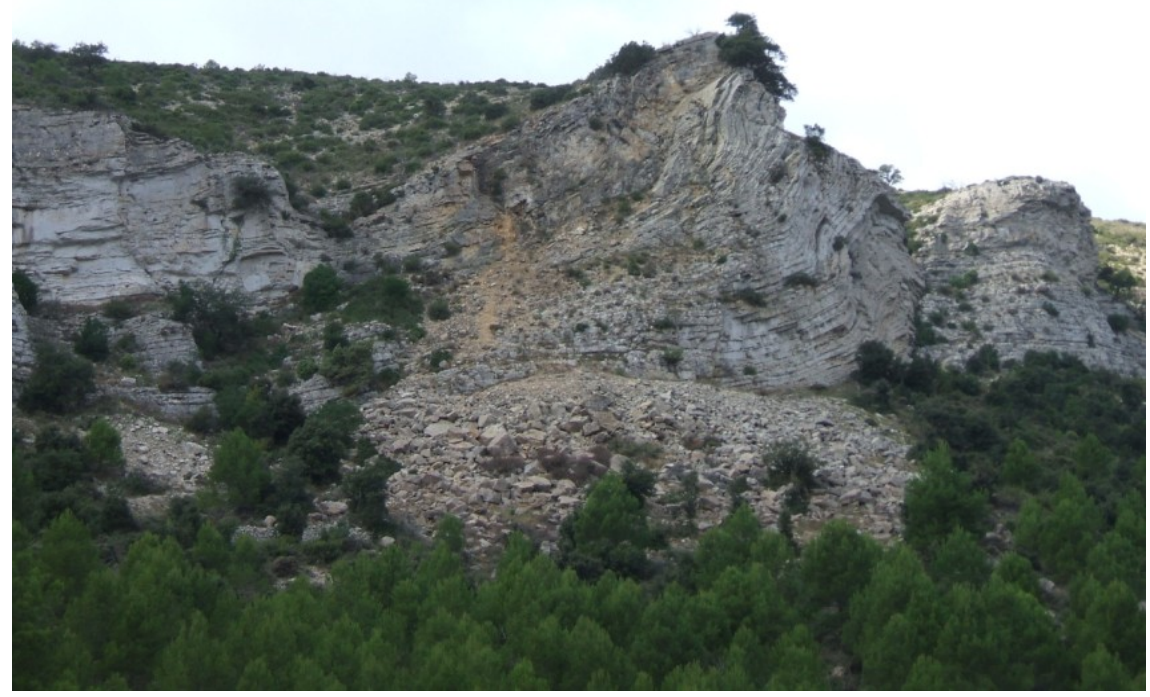

Fotografia 5. Despreniment i caiguda de blocs entre els materials carbonatats juràssics, prop de les Meliques. Fotografia de Joaquim Roset.

\subsection{Parada 6. IMMEDIACIONS DE SANT BLAI, (terme municipal de Tivissa, comarca de la Ribera d’Ebre). (Full 471).}

Després de realitzar l'aturada anterior, cal seguir pel camí que es dirigeix cap el Coll de Maula. Tot i així, arribar abans al Coll de Ventall, iniciarem una fillola per tal d’arribar a Sant Blai i a la Font de Sant Blai. Així, en arribar a aquest darrer indret, farem una nova aturada, després de recórrer uns $4 \mathrm{Km}$ més, des de la parada anterior.

Com al recorregut anterior, hem anat trobant afloraments dels materials carbonatats mesozoics del Juràssic. Aquests materials són també els que apareixen a l'indret de la present aturada. Aquí, aquests materials constitueixen un conjunt de plecs. Així, es pot veure fàcilment un sinclinal entre aquests materials. (fotografia 6). 


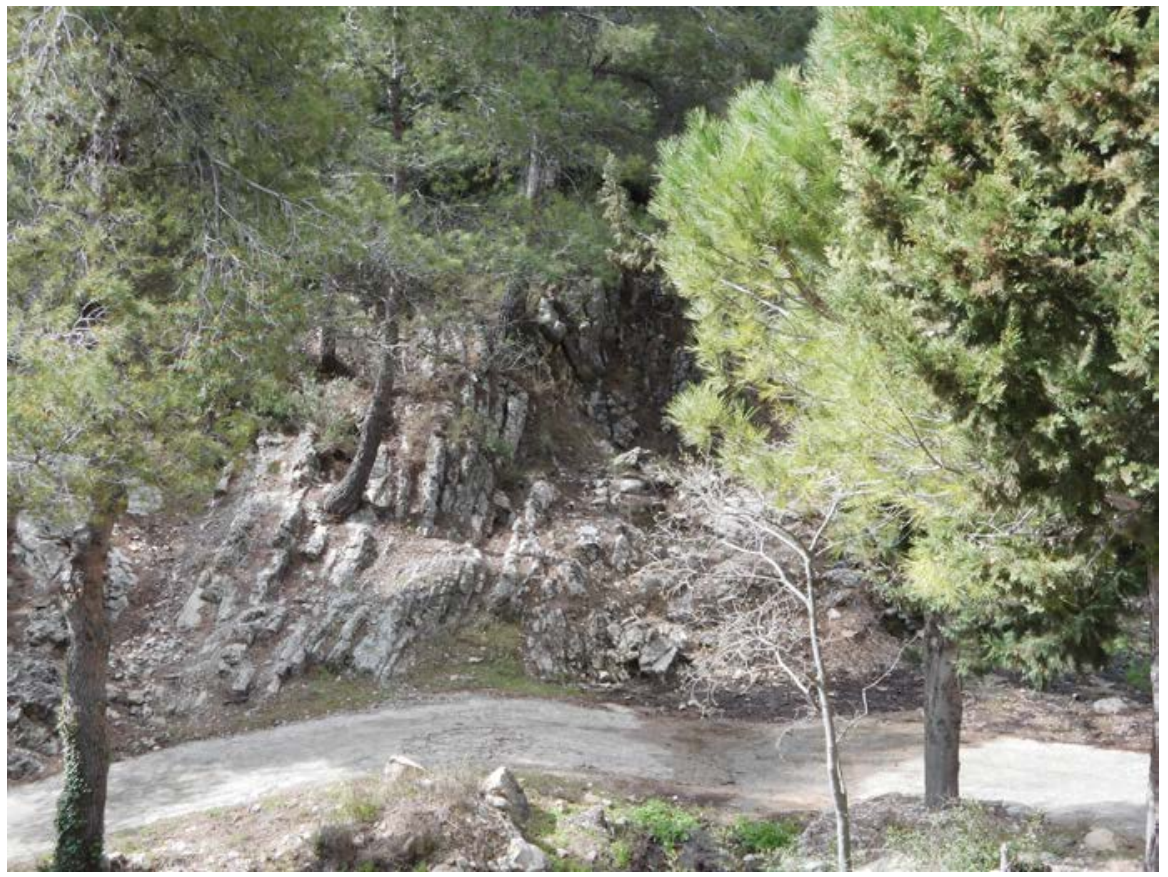

Fotografia 6. Flac septentrional del Sinclinal de Sant Blai

Per altra banda, prop d'aquest indret es pot veure un interessant congost, obert pel riuet de la Font de Sant Blai, en travessar els materials juràssics i tanmateix els triàsics, que es troben més a vall. (fotografia 7).

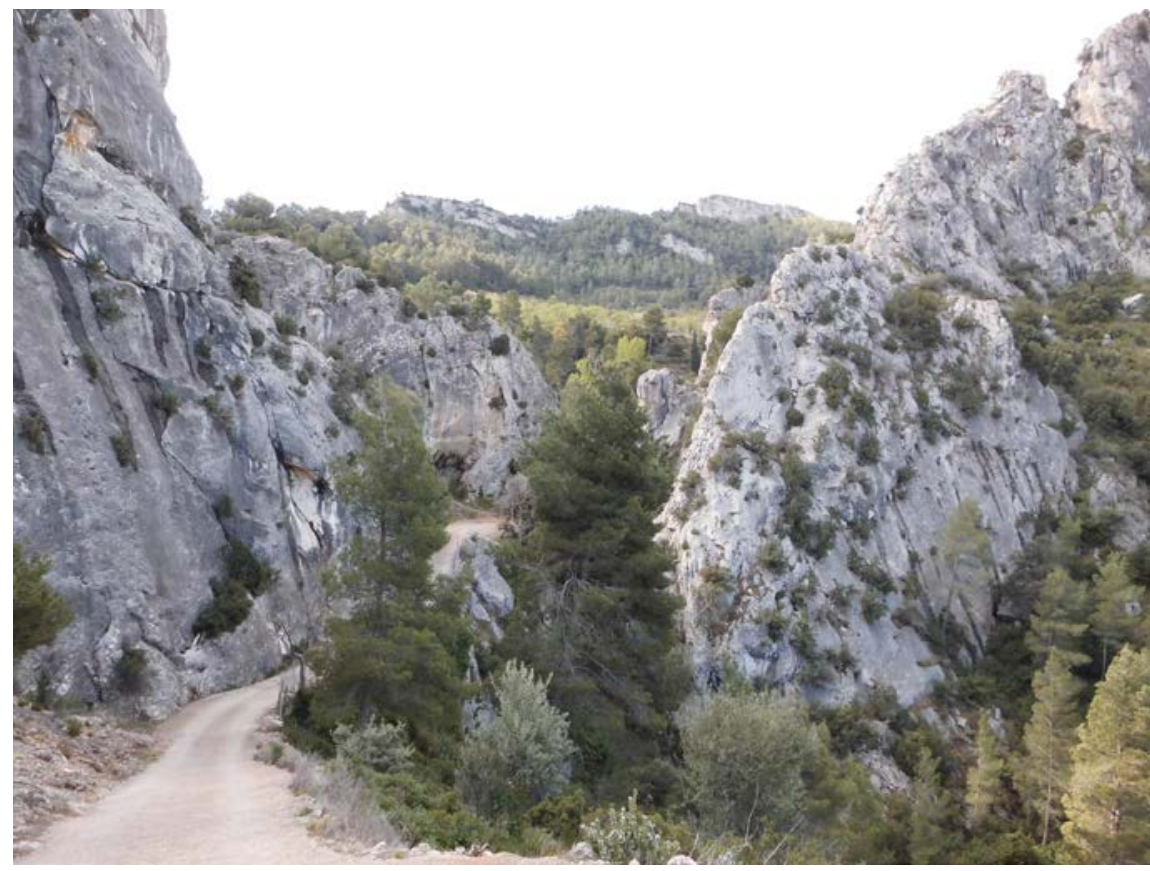

Fotografia 7. Congostet del riuet de Sant Blai. Afloraments de les calcàries juràssiques 


\subsection{Parada 7. COLL DE MAULA, (terme municipal de Tivissa, comarca de la Ribera d'Ebre). (Full 471).}

Després de realitzar l'aturada anterior, cal retornar al Coll de Ventall, per tal de continuar el camí cap al Coll de Maula i cap a Tivissa. Així, en quasi 1'5 Km des del primer coll s'arribarà al segon. En arribar-hi farem una nova aturada, a poc més de $3 \mathrm{Km}$ des de la parada anterior.

Des del Coll de Maula, mirant cap al SSW es pot fer una bona observació de la Plana de Burgar, situada prop del poble de Rasquera, per on suposadament circulava el riu Ebre. (fotografia 8).

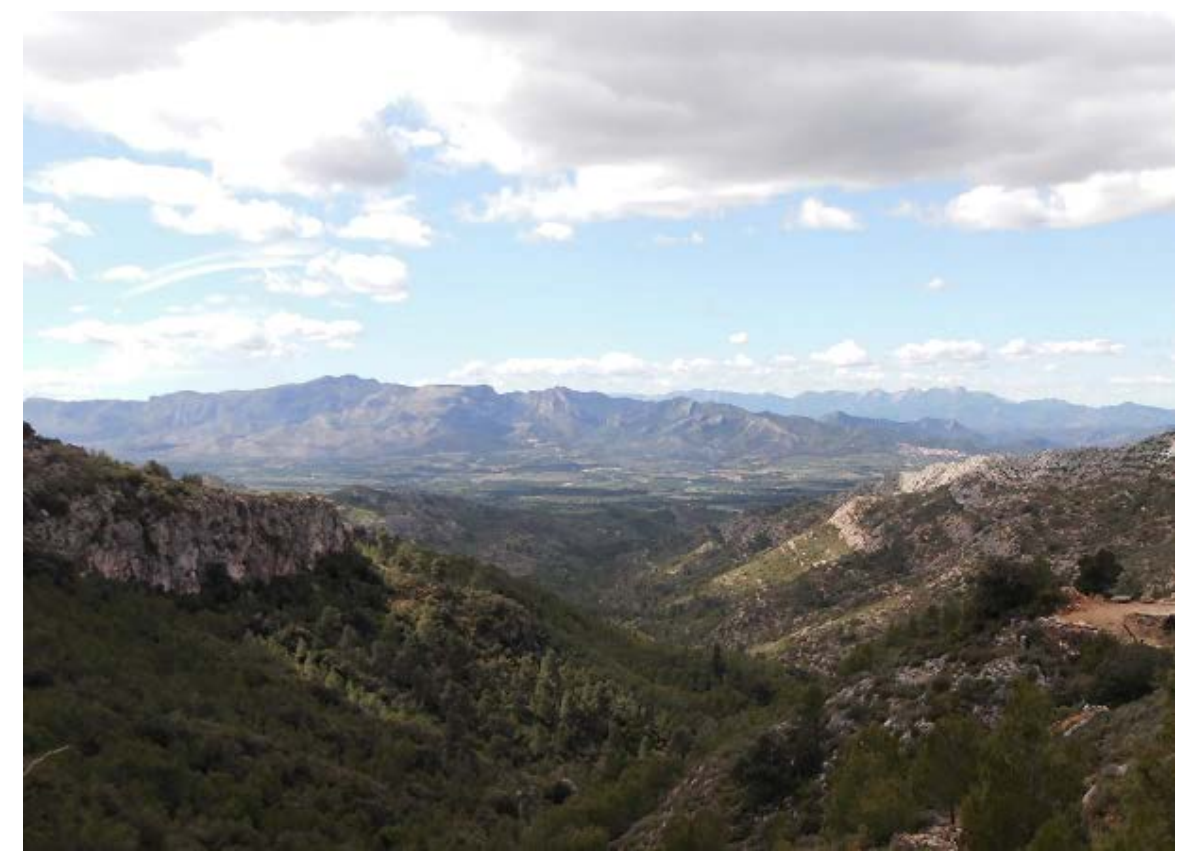

Fotografia 8. Aspecte de la Plana de Burgar des del Coll de Maula.

Darrera es poden veure els relleus del Bloc de Cardó; i més enllà els del Port

Per d'altra banda, cal dir que en aquest recorregut, haurem trobat afloraments dels materials carbonatats esmentats anteriorment. I, tanmateix, molt sovint, haurem vist presència de Belemmnites i d'Ammonites. Per d'altra banda, prop del Coll de Maula, haurem vist aflorament de les calcàries triàsiques del Muschelkalk; així com afloraments dels nivells lutítics del Keuper.

Des d'aquí, cal continuar cap a Tivissa, seguint pel camí pel que estem circulant. Així, en arribar al poble (a uns $3 \mathrm{Km}$ ), finalitzarà aquest recorregut.

En aquest indret finalitza el recorregut de l'itinerari 


\section{Bibliografia}

GUIMERÀ, J. et altri /1992).- Geologia (II), Història Natural dels Països Catalans, Vol.2, 547 pag. Enciclopèdia Catalana, S,A, Barcelona.

IGME (1978a).- Mapa Geológico de España, a escala 1:50.000, 2a Serie. Full i memória nº 471 (Mora d'Ebre). Inst. Tecnol. GeoMinero de España. Minist. Indústria. Madrid.

IGME (1978b).- Mapa Geológico de España, a escala 1:50.000, 2a Serie. Full i memória nº 472 (Reus). Inst. Tecnol. GeoMinero de España. Minist. Indústria. Madrid.

IGME (1978c).- Mapa Geológico de España, a escala 1:50.000, $2^{\text {a }}$ Serie. Full i memória no 497 (el Perelló). Inst. Tecnol. GeoMinero de España. Minist. Indústria. Madrid.

IGME (1978d).- Mapa Geológico de España, a escala 1:50.000, 2ª Serie. Full i memória nº 497 (Hospitalet de I'Infant). Inst. Tecnol. GeoMinero de España. Minist. Indústria. Madrid.

IGME (1986).- Mapa Geológico de España, a escala 1.200.000. Full i memòria, no 42 (Tarragona). Inst. Tecnol. GeoMinero de España. Minist. Indústria. Madrid.

IGME (1993).- Mapa Metalogeético de España, a escala 1.200.000. Full i memòria, $\mathrm{n}^{\circ} 42$ (Tarragona). Inst. Tecnol. GeoMinero de España. Minist. Indústria. Madrid.

MATA-PERELLÓ, J.M. (1991).- Els Minerals de Catalunya. Institut d’Estudis Catalans. Arxius de la Secció de Ciències, T.XLVIII, 506 pag. Barcelona.

MATA-PERELLÓ, J.M. (1996).- Itinerari geologico-mineralògic pel Baix Camp i per la Ribera d’Ebre: de Mont-roig del Camp a Falset i a Tivissa. Inèdit, 12 pàg., Manresa.

MATA-PERELLÓ, J.M. (1997).- Recorregut de recerca geològica i mineralògica pel Baix Camp i per la Ribera d'Ebre: des de Mont-roig del Camp a Llaberia i a Tivissa Inèdit. 18 pàg. Manresa.

MATA-PERELLÓ, J.M. (1998a).- Recorregut de recerca geològica i mineralògica pel Baix Camp i per la Ribera d’Ebre: des de Montbrió del Camp a Tivissa Inèdit. 18 pàg. Manresa.

MATA-PERELLÓ, J.M. (1998b).- Recorregut de recerca geològica i mineralògica pel Baix Camp i per la Ribera d'Ebre: des d'Hospitalet de l'Infant a Pratdip i a Llaberia, Inèdit. 12 pàg. Manresa.

MATA-PERELLÓ, J.M. (1998c).- Recorregut de recerca geològica i mineralògica per les comarques del Baix Camp, de la Ribera d'Ebre i del Baix Ebre: des de l'Hospitalet de I'Infant al Perelló, per Pratdip i per Tivissa. Inèdit, 16 pag. Manresa.

MATA-PERELLÓ, J.M. (1998d).- Recorregut de recerca geològica i mineralògica per les comarques del Baix Camp, de la Ribera d'Ebre i del Baix Ebre: des de l'Hospitalet de l'Infant al Perelló a Tivissa i al Perelló. Inèdit, 18 pag. Manresa.

MATA-PERELLÓ, J.M. (2000).- Recorregut de recerca geològica i mineralògica per les comarques del Baix Camp, de la Ribera d’Ebre i del Baix Ebre: des de Mora la Nova al Perelló, i des de l'Hospitalet de l'Infant a Tivissa. Inèdit, 12 pag. Manresa.

RIBA, O. et altri (1976).- Geografia Física dels Països Catalans. Edit. Ketres, 254 pàgines. Barcelona. 